\title{
Sciendo
}

\section{How Does Social Innovation Contribute to Solving Social Problems? A Process-Oriented Framework for Measuring Social Innovation}

\author{
Veresné Somosi Mariann \\ University of Miskolc, professor \\ Varga Krisztina \\ University of Miskolc, assistant lecturer
}

\begin{abstract}
The study defines a process-oriented framework for measuring social innovation. Social initiatives focus on meeting the needs of the community and solving their problems The local, community-based innovative ideas have a significant role. During the systematic operation of innovation, the starting point (expression of local needs) and the definition of short and long term goals as induction factors are involved in the innovation process. The starting conditions are widening in the transformation with incentive and inhibiting factors, while the stakeholders of the innovation process are also determined. As a result of the transformation, territorial-specific results will be created complementing the economic and / or social impact of the given innovation. Indicators that help measure social innovation initiatives can be identified as prerequisites, conditions of implementation and sustainability criteria, defining the structured conditions of the innovation process per phase. In addition, several levels of social innovation efforts are possible. Measuring macro-level social innovation, it is necessary to examine regional contexts, with the method of analysis of the connection network, and also with a systematic approach. Regional social innovation measurement can be used to analyze local and regional cooperation and initiatives. The study analyzes the conditions and measurement possibilities of micro-level social innovation, their generating potential and investigates the speed of organizational innovation. An example of good practice in the municipality is presented as a case study, defining the conditions that help to evaluate social innovation by determining a process-oriented framework.
\end{abstract}

Keywords: social innovation, measurement, process-oriented framework, micro-level measurement

\section{Introduction}

The conceptualisation of social innovation and the determination of its measurement levels are relevant challenges, however, these issues are only partially covered by the sources on the topic. The concept of social innovation focuses on meeting the needs of the community, emphasizing the social benefits of problem-solving innovative ideas that can be interpreted locally, at the community level. Social innovation and so-called technical innovations reinforce each other and as a result they can respond to local, community-level challenges, find solutions to everyday problems and thus enhance the well-being of the community. Innovations resulting from the expansion of innovative areas can be characterized as complementary processes.

Social innovation efforts can be interpreted at several levels.

When examining macro-level social innovation, network and systematic analysis of regional contexts is required. 
The analysis of social innovations at the meso level focuses on investigating novel regional co-operations. The exploration of contexts makes it possible to define the framework conditions that will be involved in generating regional social innovation.

The study looks at micro-level social innovations. The analysis is based on the involvement of companies, social enterprises and civil society organizations implementing social innovations at the organizational level, with particular regard to local governments. Local governments, through their novel co-operation, provide a new response to the problems of the community according to local needs, while increasing the well-being of the community. Social innovation efforts in a process-oriented framework beyond raising living standards enhance the community's ability to act, thus generating further social initiatives.

In the first part of the study, we examine the concept and approaches to social innovation, emphasizing the similarities and differences between the various trends in particular. In the literature review, we also identify the definitions that can be used to determine the process-oriented examination of social innovation.

In addition to determining the process-oriented framework, we examine the micro level of social innovation and the framework conditions that can be interpreted at the organizational level, which enable the identification of social innovations at organizational level and their generating potential. Among micro-level social initiatives, we focus on exploring the novel cooperations of the local government within the framework of structured interviews. Social innovation as a new means and model to help the process of catching up is a kind of good practice in the toolbox of local governments, especially in disadvantaged regions.

An example of local government practice is presented as a case study, defining the set of conditions that help to investigate social innovation by determining a process-oriented framework.

\section{Theoretical definition of social innovation}

Nowadays it has become increasingly widespread that several basic problems of the economy and society (including poverty, unemployment, exclusion, bad access to food, water, technology, medicine, information etc., lack of education, prejudice, crime, environmental destruction...) are impossible to solve without novel cooperation between the actors of society, without the direct creative participation of citizens, or without social innovation. In the process of social innovation, the idea of the innovation and the resources that can be mobilized for implementation, the innovative organizational framework of implementation and sustainability are equally important. The definition of social innovation is not unified, it is divided by the determinants and the users of the concept. Apart from common features such as enhancing well-being, involving the society or meeting community needs, the approaches made by concept creators are different, thus it is a basic requirement to make a transparent and consistent structure (Table 1).

Many definitions have been reviewed during our research, and thus social innovation can be interpreted as a concept that results in meeting the needs of the society, along new or novel co-operation and structures. Social innovation efforts result in the renewal of the society, and also encourage the members of the society to act.

The theoretical approach to social innovation, as well as essential differences in each trend are summarized in Table 2. After the first mentioning of the concept of social innovation (Tarde, 1899, Hoggan, 1909), Dénes Gábor examined the essential role of social initiatives in 1970, analyzing scientific, technical, biological and social innovations, and concluded that technical innovations had significantly got away from social innovations. In his view, the overwhelmingness of technological innovations has caused disproportion in the process of innovations, as efforts to increase social prosperity are lagging behind and are marginalized. In this sense, social innovation is a comprehensive framework program, which is not primarily an initiative going along with technical innovations, but a "reform" that controls and regulates all the innovations (Gábor, 1970). Social innovations are inseparable associates of technological innovations, and innovations can be interpreted as complementary processes. The new innovative bases - as the field of social innovation - help to realize and improve the technical innovations, while at the same time increase each other's strength and this way they are able to respond to the current challenges of society. While giving the theoretical definition to social innovation, it becomes important to innovate in every area of life, and innovation initiatives should not only be confined to technical and economic fields (Drucker, 1985). According to another approach to social innovation (Mumford, 2002), it means generating and implementing new ideas, in which social interactions are organized to achieve a common goal. Another trend of social innovation theories (Hazel-Onaga, 2003) focuses on solving social problems, highlighting the importance of collaboration 
among stakeholders. There is also a point of view according to which the concept emphasizes the value created by social innovation (Mulgan et al, 2007), highlighting the fulfillment of social demand as the main goal.

A significant trend in social innovation theories emphasizes the improvement of the quality of life by solving social problems (Pol-Ville, 2009; Peyton Young, 2011). We accept and appreciate the approach which focuses on the process resulting from increasing social well-being. In our research, social innovation is identified as "providing new or novel responses to a community's problems with the aim of enhancing community well-being"(Kocziszky et al., 2017). In addition to rising living standards, the emergence of novel structures and the promotion of the capacity of society to act are emphasized. In a normative approach, "social innovation is a process that increases the willingness of the community to act in the form of new or novel collaborations"(Balaton-Varga, 2017).

To justify the empirical research, we consider it essential to define the characteristic elements of social innovation, which is a good basis for implementing our micro-level studies (Figure 1).

\section{Some features of social learning}

The development of social innovation can basically be divided into two subsystems. One is the central, political subdivision of development, which usually aims to develop values regarded as public goods by public subsidies. The other subsystem is local, which is the people's ambition to improve their environment, economics and viability, which is rich in information, practical knowledge, but usually lacks resources. The two systems are linked in many aspects, but they are still significantly different. The central subsystem allows for greater scale planning with the use of EU and national resources, but at the same time it often becomes the victim of various political and economic conflicts of interest (Nemes-Varga, 2013). Local developments, however, can only achieve structural changes and results in an integrated system. Many researchers are concerned with the issue of co-operation, and many of them also see a big challenge in general lack of trust, low willingness to cooperate, institutional and political culture.

Social innovation is created by other mechanisms, much more than technological innovation. It can be explained by the three dimensions of social innovation (EC 2013):

- Social innovation as the social process of creating innovation, that is innovation is not created in the traditional way (e.g. in a research institute), but with the participation of the society and the civil sphere

- Social innovation as an innovative solution prioritizing social responsibility, where responses to problems are in line with social values and norms, opposing profit maximizing business processes

- Social innovation, focusing on the renewal of the society, its aim is to change attitudes and social structure. In this case, we suppose that social innovation is implemented by changing social norms, values and relationships.

Social innovation should not be approached exclusively as a bottom-up activity since innovation and its support often originate from a macro level.

Innovation requires knowledge creation and learning. According to Reed et al. (2010), social learning is a process in which understanding and dealing with the problem involves a change that goes beyond the individual as the process takes place at a social level, in a community, through social interactions.

In the approach of Kozma et al. (2011), the place and level of the social learning process is of particular importance. Social learning (Nemes-Varga, 2015) is a process in which a community becomes capable of an action or activity that has not been able to do before. Social learning is based on the expansion of three types of knowledge:

- $\quad$ cognitive, scientific, technological knowledge,

- $\quad$ practical knowledge,

- $\quad$ situational knowledge.

In our research, we have come to the conclusion that the creation of social innovation should be supported by artificial intelligence, as the problem to be solved is poorly structured.

According to the literature, knowledge generation is a program that, on the basis of its analytical capabilities, is able to define and weight problems and propose a possible solution instead of the previously accepted versions. The system supports the recognition of the "best solution" through a "knowledge bank" during the problem solving process. This way it 
can be a useful supporter of decision preparation. Researches on the structure and functioning of knowledge generation (Expert Systems) began in the mid 1950s (by studying artificial intelligence) (Puppe, 1991). Research underwent a major change in the 1970s when researchers turned to knowledge-based systems.

The proposed knowledge generating system consists of two main parts:

- a user interface that allows data retrieval, grouping and comparing data, and defining and presenting the results of calculations,

- developing expert solutions.

Figure 2 illustrates the process of knowledge generation, which can be of fundamental importance for the creation, implementation and maintenance of social innovation.

After the process of knowledge generation, we briefly summarize the test model that gave the framework to our thinking, and on the basis of which we deal in detail with micro-level social innovation in this study (Figure 3).

\section{Investigating micro-level social innovation}

Social innovation, similarly to technical and economic innovations, is both intelligible and measurable at micro, meso and macro level, and has a key role in competitiveness.

The levels of social innovation (Kocziszky et al., 2017)

- $\quad$ micro (organisational) level,

- $\quad$ meso (settlements, regional) level,

- macro (national) level,

- global level.

Social innovation formulates novel solutions to challenges that are in tight connection with regional disproportions.

Due to the disproportions arising from the different levels of economic development, areas in peripheral situation with the need for catching up, get to the fore. Besides the so-called technical innovations, social problems can be solved by social means and the creation of new organizations. In the catching-up process, innovative ideas that can be interpreted at the local and community level as well as the micro-level social innovation activities play an important role. Innovations arising from the expansion of innovative areas can be considered as complementary processes. Social and technical innovations are in close contact with each other. If there is a change in the economy, it is also obvious for social changes to occur. As a result of a questionnaire survey conducted in the autumn 2017 (Tóthné - Varga, 2017), it can be stated:

- those who implement business innovation will, after a while, generate social innovation during novel cooperation,

- social innovation is often followed by business innovation.

Social innovation as a new means is the answer to everyday challenges. Social innovation efforts are new or novel structures, collaborations that help peripheral areas to catch up as effective and sustainable solutions.

The European Union's convergence strategy justifies the examination of the catching-up tools that mean a breakthrough for disadvantaged areas. In the peripheral areas, the low number or the total lack of technical innovations requires the implementation of innovative co-operations and programs that support the enhancement of competitiveness by involving civil initiatives and provide a higher standard of living at a social level. In the attempts to eliminate regional disparities, the role of new co-operations requiring active involvement of local governments and citizens is outstanding.

It is a basic task to investigate and coordinate those involved in the multi-player territorial competition (Ritter et al., 2013). Those involved in the multi-player territorial competition (Lengyel, 2003) are as follows:

- the local government,

- $\quad$ economic municipalities (economic chambers, entrepreneurial associations, trade boards),

- knowledge transfer institutions (higher education, vocational training),

- developing agencies. 
It is also an important task to investigate the relationship between disadvantaged settlements, including their organizations and institutions, to take local initiatives into account and to utilize novel results of co-operation. In the new co-operation, the local government plays a prominent role as a coordinating, motivating and mediating actor in the pursuit of social innovation endeavors.

The measurement process of micro-level social innovation is complicated by several factors. The starting point for measuring innovation is determining appropriate indicators and their identification as input, output or impact indicators, referring to the process of systemicity. The question is what we should measure. The task is complex because the literature has not directly addressed the issue so far, and the question of measurability is of vital importance while getting the definition of the indicators. The determination of the measurement structure is also complicated by the large number of variables, and this way it requires a reduction in the case of each factor.

During the examination of relationships, factor analysis can be used to identify indicators that help measure social innovation. Indicators to help measure social innovation initiatives at organizational level can be determined on the basis of the following criteria (G. Fekete et al., 2015):

- preconditions,

- conditions of implementation,

- $\quad$ sustainability conditions.

Preconditions make it possible to define the innovations that appear as a starting factor in the convergence process. Preconditions typical of successful social innovation processes of a given settlement (altogether innovation activities) are as follows:

- ability to recognize a problem,

- $\quad$ willingness to change,

- $\quad$ striving for cooperation.

When measuring innovation activity, indicators based on the above categories help determine the measurement process (Figure 4).

The conditions for achievement are factors that play a key role in the catch-up process in the realization of successful social innovations In the short term, the innovation process is effective when as its result social transformation and community response to social problems occur. Implementation conditions for successful social innovation efforts of a given settlement (altogether framework conditions) are as follows:

- $\quad$ proficiency in the subject (information and knowledge),

- the personal competence of the heads of local governments, other state, economic and civil organizations: entrepreneurial, managerial, cooperation and creative skills

- $\quad$ a resource-building framework (formal-regulated and informal-relationship),

- instituitional framework,

- political framework,

- conditions of social sphere.

The successful implementation of social innovations is measured along specific indicators based on the factors determined above (Figure 5).

Sustainability conditions ensure the long-term success of the catching-up process as a means of renewing and transforming society. The conditions ensuring the sustainability of social innovation in a given settlement (altogether results) such as tracking, evaluation, feedback using the following area-specific results:

- education,

- health,

- employment,

- housing,

- $\quad$ social capital and networks, 
- political participation,

- environment.

The measurement of the results of the social innovation process and the analysis of its long-term effects require the selection of indicators based on the above categories (Figure 6).

\section{Good example by local government - case study}

According to Zamf, "by social innovations we can achieve new paths and goals, especially new forms of organization, a new lifestyle, new regulations, which change the direction of social changes, make problems more easily soluble and and they become valuable, adaptive and institutionalized" (Szörényiné, 2015). In the case of settlements, innovative solutions of local governments mean new collaborations, which result in well-being and increase the power of action of the community. Mayors, like Schumpeter's former "entrepreneurs", are involved in the processes of innovations as innovators along new collaborations and structures.

One of the characteristics of disadvantaged settlements is the disruption of demographic balance. The causes are as follows:

- aging,

- inequality between education levels,

- $\quad$ migration of disadvantaged citizens (particularly of the Roma).

These challenges require innovative co-operation between local governments and NGOs. Self-government should not be interpreted as an isolated process, separated from citizens, but an attempt should be made to cooperate. A new governance model is needed which is holistic and according to which the role of citizens in the implementation of social processes is growing (Varga, 2017).

When studying the novel co-operations between local government and NGOs as well as enterprises, we examined settlements which are located in disadvantaged districts and use social innovation as a means to increase catching-up and living standards. The number of districts to be developed by a complex program determined on the basis of the district development indicator in Hungary on January 1, 2015 was 36, typically in the peripheral part of the country. Most developing districts are located in Szabolcs-Szatmár-Bereg county, in the eastern part of the country, with a total of 9 districts requiring a comprehensive programme implemented along comprehensive plans.

Every second citizen of Szabolcs-Szatmár-Bereg county lives in a district that needs complex development. Every third and fourth inhabitant of Hajdú-Bihar and Borsod-Abaúj-Zemplén counties live in a district requiring development based on a complex program. There are more than 980,000 people living in the districts, and $64 \%$ of them live in the three counties named above (Central Statistical Office).

The district of Nyírbátor (Szabolcs-Szatmár-Bereg county) is ranked 13th in the list of districts to be developed, with three towns (Nyírbátor, Nyírlugos, Máriapócs) and 17 municipalities belong to it. The dynamic catch-up and development of Nyirbátor is largely determined by the relatively high proportion of disadvantaged, mainly Roma population. The town's getting onto the path of long-term growth clearly depends on the overall management and social integration of the disadvantaged population. The main challenges of the examined settlement (ageing, migration of disadvantaged citizens) require innovative co-operation between the local government, businesses and NGOs.

In the survey we paid particular attention to social innovation initiatives which can be identified as good practices and generate further innovations. While studying the situation in the settlement of Nyírbátor, we conducted 3 qualitative interviews with the mayor's cabinet and the heads of NGOs.

The main question groups of semi-structured interviews:

- general organizational information,

- social innovation as a special concept,

- implemented social innovations,

- planned social innovation efforts,

- regional cooperation (and opportunities). 
Four critical areas were identified during the study:

- $\quad$ education (high quality and adaptation to needs),

- $\quad$ employment (labor market programmes based on personal mentoring),

- health (improvement of health status and prevention),

- housing (improving housing conditions

Social innovation efforts as new model and means provide a solution to address problems in these areas. The study shows that social innovation initiatives are able to increase living standards, although some obstacles can be identified:

- $\quad$ lack of expertise,

- leck of volunteering,

- the local problem as a local feature makes it difficult to define general solutions.

In Nyírbátor in 2015 a complex programme was launched to improve the living conditions of Roma communities. The problems identified by the local government, local institutions and entrepreneurs, as well as the Community Action Group (KACS) are the same as the challenges identified in critical areas (Figure 7).

Determining the cause-and-effect relationships between the factors is complicated due to their impact on each other, and the unclear factors of the sequence of events, but it can be stated that if a disadvantaged citizen's housing conditions are inadequate, it can lead to health problems. Health problems can cause learning difficulties, which can lead to reduced labor productivity, which may lead to the deterioration in housing conditions. What was needed was the improvement of housing conditions, the promotion of local retail services adapted to local needs, the increase of the proportion of community programmes and spaces, and the expansion of community and social services. In addition, the development of adequate transport conditions is also emphasized, but the improvement of physical infrastructure alone is not enough to increase the social welfare of the population. In order to increase the standard of living of the society, taking the disadvantaged position of Nyirbátor into account, social innovation efforts are indispensable. Within the framework of social innovation, the role of the local government is emphasized, which (in cooperation with the enterprises and civil organizations of the settlement) helps to implement training and labor market programmes and to improve the accessibility of social services and public information through innovative initiatives and programmes. We studied a great number of novel activities among the measures which were different from the traditional self-government model in the town's life. The local self-government with the traditional governance is lagging behind the active initiatives based on participation, this way it is necessary to define a new self-government model. The new self-government model is cooperative and consultative, supporting citizens' decisions.

In the context of social innovation efforts Nyírbátor defined interventions that treated infrastructure shortcomings, as well as the problems related to the labour market, education, health etc. of the disadvantaged population in the residential environment in an integrated manner. Within the so-called "soft interventions" supporting the social integration of disadvantaged people, various labour market trainings, measures of employing the long-term unemployed and programmes aiming at the development of civil society were implemented. The novelty of the interventions was that the elaboration of the programmes was preceded by various professional forums, round tables (businesses - local government disadvantaged population) and open days. Socially innovative solutions have emerged based on real social dialogue and partnership, in the course of which partnerships go beyond the usual formalities, and which result in a truly active way of mutual thinking.

The city organized two planning meetings to support the development of employment and education standards. In addition to the local government, representatives of the business sector, heads of elementary schools and the representatives of disadvantaged population (Romas) participated in the discussions. The long-term goal is that more local Roma people should work in the growing number of workplaces in Nyírbátor. During the programmes, the leaders of the educational institutions made it clear what each institution requires in order to be effective in participating in the local Roma integration process and in the effective cooperation. Representatives of the business sector presented development plans, ideas and labor market needs. They determined what each of the economic operators can add to the objectives pursued, how they can help the process of integration and what they need to contribute to the effective cooperation. The actual dialogue helped to inform the disadvantaged population, clarify the needs and requirements, and define the novel co-operation of 
the local government. A form of social innovation is the introduction of mutually beneficial initiatives which - together with the effects of rising unemployment - result in more active citizens and strong self-organization.

The Nyírbátor programme mainly supports the education and employment of the Roma. Identifying short and long-term goals will help integrate Roma into work. The participants of the sub-program (local government, business sector representatives, NGOs) identified the long-term goals as the first task and then the shorter-term activities to achieve the objectives pursued.

The tasks are given: targeted measures, revealing the causes of marginalization, the cooperation of Roma and non-Roma communities - all lead to the growth of well-being. Companies can contribute to the implementation process by providing information, organizing various training programmes, scholarships and mentoring programmes, and the local government can support convergence with the help of mediators (Roma and non-Roma ethnic intermediaries), in addition to preparatory work and mentoring.

The members of the Community Action Group (KACS) can get involved in the program by having accurate information on the disadvantaged population, as well as the specific interventions, and by getting the Roma community to know about them. They also have an important role to play in liaising with the institutions. The training of Roma mediators and their inclusion in the program will enable the improvement of the relationship between Roma parents and the school, Roma parents and teachers, and Roma and non-Roma parents. A kind of awareness is being created about the importance of learning, and increasing the chances of Roma children to succeed.

By means of innovative cooperation the local government has defined specific actions and tasks in the short and long term. Short-term measures are essential to achieve long-term goals.

Education (Figure 8):

For the disadvantaged population, the area of education is a critical point. In order to increase social welfare, short-term and long-term goals have been identified during the program. Long-term goals in education are as follows:

- $\quad$ every child should have access to the training most suitable for their abilities

- integrated education,

- motivated parents and children,

- $\quad$ preventing children from dropping out of school,

- cooperation between the institution and the parent,

- $\quad$ support,

- $\quad$ destruction of prejudices

Meeting long-term objectives is achieved through defining and implementing short-term actions. Short-term goals in education are as follows:

- improving communication between actors,

- taking care of Roma values and culture,

- getting parents to be involved in school programmes,

- visiting families, giving assistance,

- $\quad$ mentoring (involving Roma parents),

- $\quad$ programmes to help taking responsibility for their own life,

- creating a computer workshop,

- $\quad$ having a subject of Health Education at school

- life management programmes for parents

Employment (Figure 9):

Convergence can be achieved by identifying critical areas and supporting intervention in these areas. In addition to raising and ensuring the quality of education, the implementation of employment-promoting labour market programmes is crucial. Long-term goals in the field of employment are as follows: 
- Roma workers in all areas of labour market,

- employers' openness and acceptance,

- $\quad$ well-qualified, motivated, disciplined, skilled workforce.

- Short-term goals in the field of employment:

- providing information about employment,

- giving positive examples,

- vocational training adapted to employers' needs,

- mentoring

- talent management,

- scholarship system.

During the realization of the catching-up opportunities we identified local characteristics, obstacles and priorities as important factors. The framework conditions for improving living conditions at the local level together lead to convergence. Particularly important is the identification of people affected in the process, the role of communication (providing information), planning financial resources, attempts to change attitudes and institutional background. In addition to these factors, the local social care system plays a key role in implementing the catching-up process during the co-operation (Figure 10).

In response to local needs - unlike in the past - the local government did cooperate and continuously consulted with the entrepreneurs, civil organizations, institutions and citizens of the town to implement the programme. In an innovative way, they initiated an effective dialogue and resorted to novel solutions, while encouraging the public to act. This is social innovation itself.

\section{Conclusions}

When measuring social innovation at the micro level, it is important to identify the framework conditions that can occur as a precondition, a condition for implementation and a sustainability factor. The study requires an integrated model which is able to handle framework conditions, organizational activities and results in a complex way. In the case of social innovation at the organizational level, the measurement of an innovative process based on the active participation of local governments requires the identification of the mayor as an innovator. The innovation efforts of the local government are created by the stimulating factors (framework conditions), and the results of the innovation process can be specifically assessed and analyzed (Figure 11). In the model, framework conditions play a regulatory role in the innovation activity as institutional, political, resource-based and social factors. The results (the whole of municipal performance and social results) comprise a stage of social innovations, interacting with local government activities and framework conditions, examining the specific needs of innovation, that is the social change. In the analysis of the process of social innovation, it is important to identify the relationships which reflect the interaction between the factors influencing the innovation activity (Schmitz et al., 2013) and which form feedback loops in the innovation process (social innovation enhances the capacity to act and results in new innovations). A holistic approach is needed that addresses critical areas in a complex way and examines the interaction between problems in critical areas (education, employment, healthcare, housing). Co-operation between local people involved results in the most effective solution based on the participation of the local government, NGOs, Roma and nonRoma communities. The signs of the most effective solution is cost-effectiveness, high proportion of beneficiaries, rapid success, scheduling and sustainability, i.e. strategic thinking.

\section{References}

[1] An Interview with the Mayor of Nyírbátor, Antal Máté on 24/07/2017 and 08/08/2017

[2] Balaton, K. - Varga, K. (2017): Social innovation and competitiveness - a literature review of the theoretical work in the field, REVIEW of Economic Studies and Research Virgil Madgearu, 10, No. 2, pp. 27-42. ISSN 2069 $-0606$

[3] Central Statistics Office, Hungary (2016): A komplex programmal fejlesztendő járások jellemzői (Characteristics of the districts to be developed with the complex program)

[4] EC, E. C. (2013). "Social innovation research in the European Union: approaches, findings and future directions." Publications Office of the European Union, Luxembourg. 
[5] G. Fekete, É. et al. (2015): Társadalmi innovációs szolgáltatások a Miskolci Egyetemen (Social Innovation Services at the University of Miskolc), http:/lt-modell.unimiskolc.hu/files/9810/10_T_\%C3\%96sszefoglal\%C3\%B3.pdf

[6] Gabor, D (1970): Innovations: Scientific, Technological, and Social, Oxford University Press

[7] Hazel, KL. - Onaga, E. (2003): Experimental social innovation and dissemination: the promise and its delivery, Am J Community Psychol, 32(3-4), pp. 285-294.

[8] Kocziszky, Gy. - Veresné Somosi, M. - Balaton, K. (2017): A társadalmi innováció vizsgálatának tapasztalatai és fejlesztési lehetöségei (Experience and possibilities for developing social innovation research), Vezetéstudomány (Budapest Management Review), XLVIII. évf., 6-7. szám, pp. 15-19. ISSN 0133-0179

[9] Kocziszky, Gy. - Veresné Somosi, M. (2016): Generating social innovation with knowledge engineering, Procedia - Socila and Behavioral Sciences 223, pp. 167-174.

[10] Lengyel, I. (2003): Verseny és területi fejlődés: térségek versenyképessége Magyarországon (Competition and territorial development: the competitiveness of regions in Hungary), Szeged, JATEPress

[11] Mulgan, G. et al. (2007): Social Innovation - what it is, why it matters and how it can be accelerated, The Young Foundation, ISBN 1-905551-03-7 / 978-1-905551-03-3

[12] Mumford, M. D. et al. (2002): Leading creative people: Orchestrating expertise and relationships, Research Nebraska, Leadership Quarterly, 13(6), pp. 705-750. DOI: 10.1016/S1048-9843(02)00158-3

[13] Nemes, G. - Varga, Á. (2015): Társadalmi innováció és társadalmi tanulás a vidékfejlesztésben - sikerek, problémák, dilemmák (Social innovation and social learning in rural development). In: „Balance and Challenges” IX. Internatonal Scientific Conference (ed.: Veresné Somosi M.), Miskolc, pp. 434-444. ISBN 9789633880981

[14] Pol, E. - Ville, S. (2009): Social innovation: Buzz word or enduring term? The Journal of Socio-Economics 38. pp. 878-885.

[15] Ritter, K. - Nagy, H. - Tóth, T. (2013): Hátrányos helyzetű vidéki térségek és helyi fejlesztési lehetőségeik egy észak-magyarországi példán keresztül (Disadvantaged rural areas and their local development opportunities through a North-Hungarian example). In: Lukovics M. - Savanya P. (ed.): Új hangsúlyok a területi fejlődésben (New emphasis on territorial development). Szeged, JATEPress, pp. 224-242.

[16] Schmitz et al. (2013): Paving the Way to Measurement - A Blueprint for Social Innovation Metrics. A short guide to the research for policy makers. A deliverable of the project: "The theoretical, empirical and policy foundations for building social innovation in Europe" (TEPSIE), European Commission - 7th Framework Programme

[17] Szörényiné Kukorelli, I. (2015): Vidéki térségeink innovációt befogadó képessége - Egy kutatás tapasztalatai, Tér és Társadalom (XXIX.) pp. 97-115.

[18] The World Bank - European Committee (2015): Kézikönyv - A roma közösségek életkörülményeinek javítása helyi szinten (Handbook - Improving the living conditions of Roma communities at local level)

[19] Tóthné Kiss, A. - Varga, K. (2017): Üzleti és társadalmi innovációk beágyazottsága, kapcsolata - előadás (Embeddedness and Relationship of Business and Social Innovations - lecture). International conference on university-based entrepreneurship and regional development: Theory, empirics and practical implementation conference, 30th November 2017

[20] Varga, K. (2017): Társadalmi innováció az önkormányzatok müködésében (Social innovation in the operation of local governments), In: Lipták, K. (ed.): Társadalmi innováció és felelősségvállalás Észak-Magyarországon (Social Innovation and Responsibility in Northern Hungary), Miskolc, pp. 7-15.

\section{Tables}

Table 1 The approaches of social innovation conceptualized by users, Source: own compilation

\begin{tabular}{|l|l|}
\hline DEFINITIONS AND USERS & INTERPRETATION \\
\hline scientific associates, researchers & $\begin{array}{l}\text { scientific definitions (normative interpretations, utility, distinction } \\
\text { from technical innovation) }\end{array}$ \\
\hline civil sphere, civil society organisations & mission, emphasizing the role of social enterprises \\
\hline government, their institutions & administrative, society-centered interpretation \\
\hline intergovernmental bodies (EU, OECD) & $\begin{array}{l}\text { theoretical and / or methodological approach, measurement } \\
\text { questions }\end{array}$ \\
\hline
\end{tabular}


Table 2 Interpretations of the concept of social innovation, Source: own compilation based on G. Fekete, 2015.

\begin{tabular}{|l|l|l|}
\hline AUTHOR & YEAR & CONCEPT, THEORY \\
\hline Tarde, G. & 1899 & society as an expanding network economy \\
\hline Hoggan, F. & 1909 & social substitution \\
\hline Gábor, D. & 1970 & technical innovations have been torn apart from social innovations \\
\hline Drucker, P. & 1980 & innovation is also a social category \\
\hline Zapf, W. & 1989 & change in society \\
\hline Mumford, D. M. & 2002 & new ideas - common aim \\
\hline Hazel, C. & 2003 & solving social problems: people involved, new collaborations \\
\hline Mulgan, G. & 2007 & social value created by social innovation \\
\hline Pol, E. - Ville, S. & 2009 & improving quality of life \\
\hline
\end{tabular}

\section{Figures}

Figure 1 Characteristics of social innovation Source: Kocziszky et al., 2017

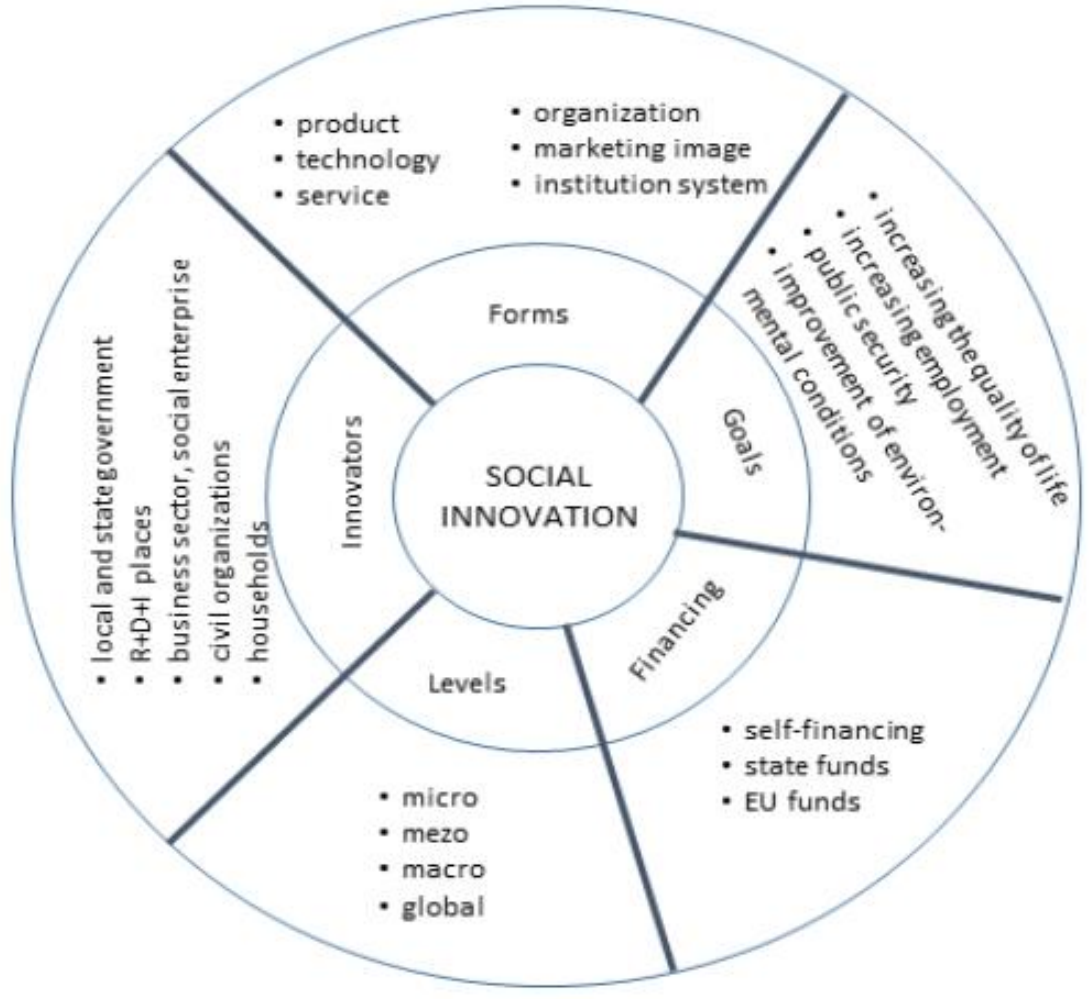


Figure 2 The process of knowledge generation, Source: Kocziszky-Veresné Somosi, 2016

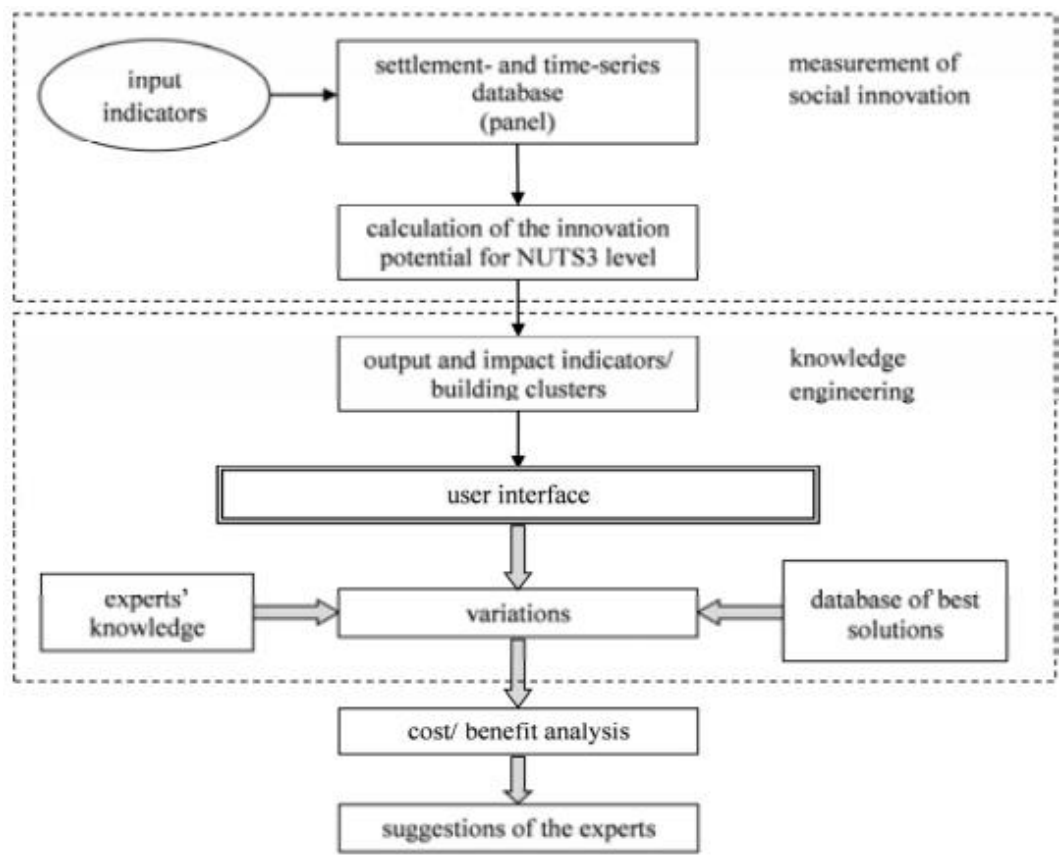

Figure 3 Framework model of analysis, Source: own compilement

FRAMEWORK MODEL

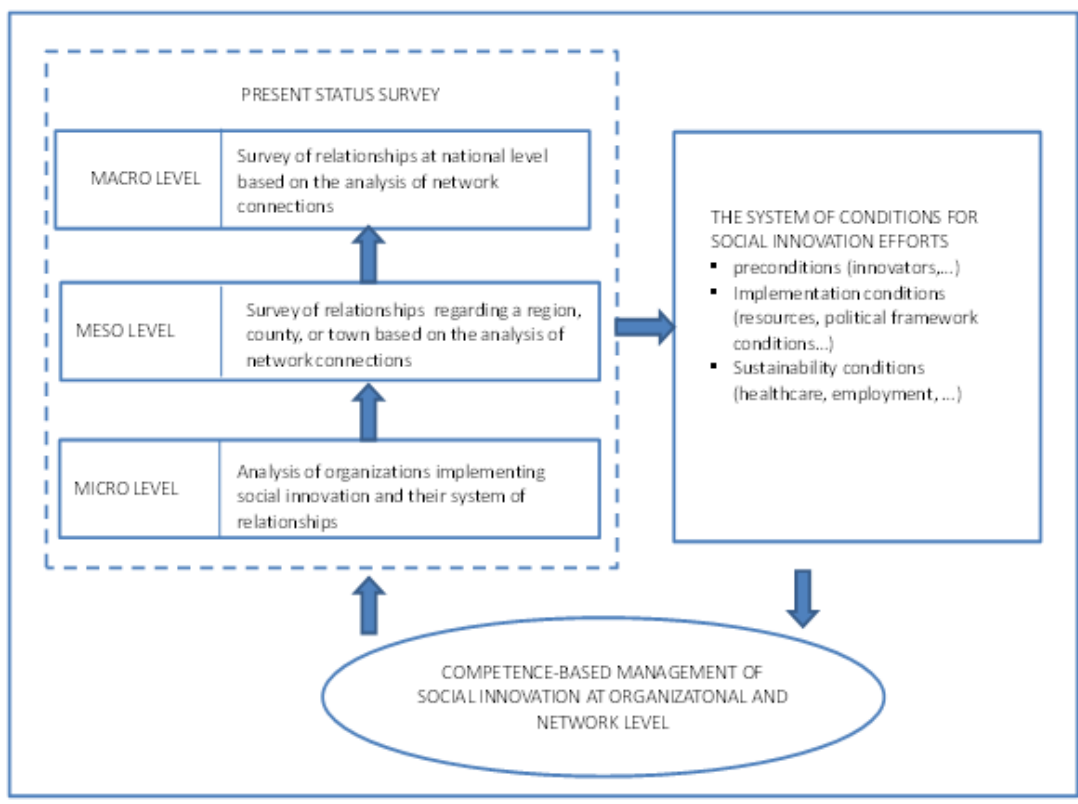


Figure 4 Prerequisites for social innovation: innovative activity measurements, Source: own compilation based on Schmitz et al., 2013

\begin{tabular}{|c|}
\hline $\begin{array}{c}\text { Innovative investments in } \\
\text { social innovation }\end{array}$ \\
\hline investments made by \\
business organizations \\
- investments by state actors \\
- investments by self- \\
governments
\end{tabular}
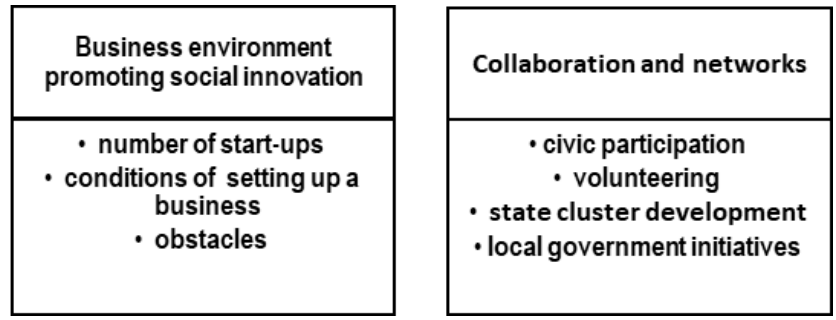

Figure 5 Conditions for implementing social innovation: measuring framework conditions

Source: own compilation based on Schmitz et al., 2013
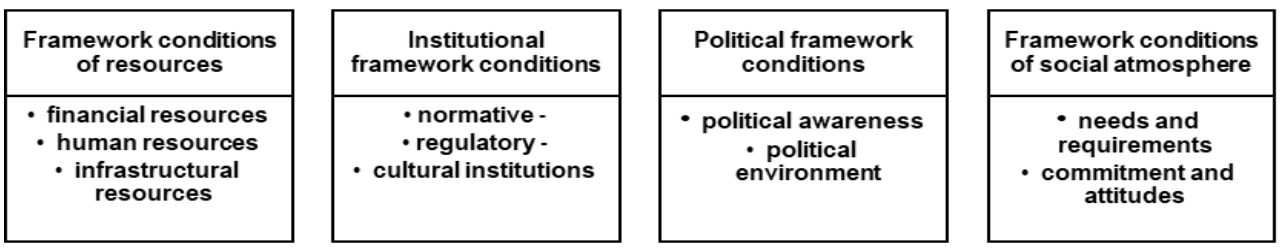

Figure 6 Conditions for sustainability of social innovation: measuring outcomes, Source: own compilation based on Schmitz et al., 2013
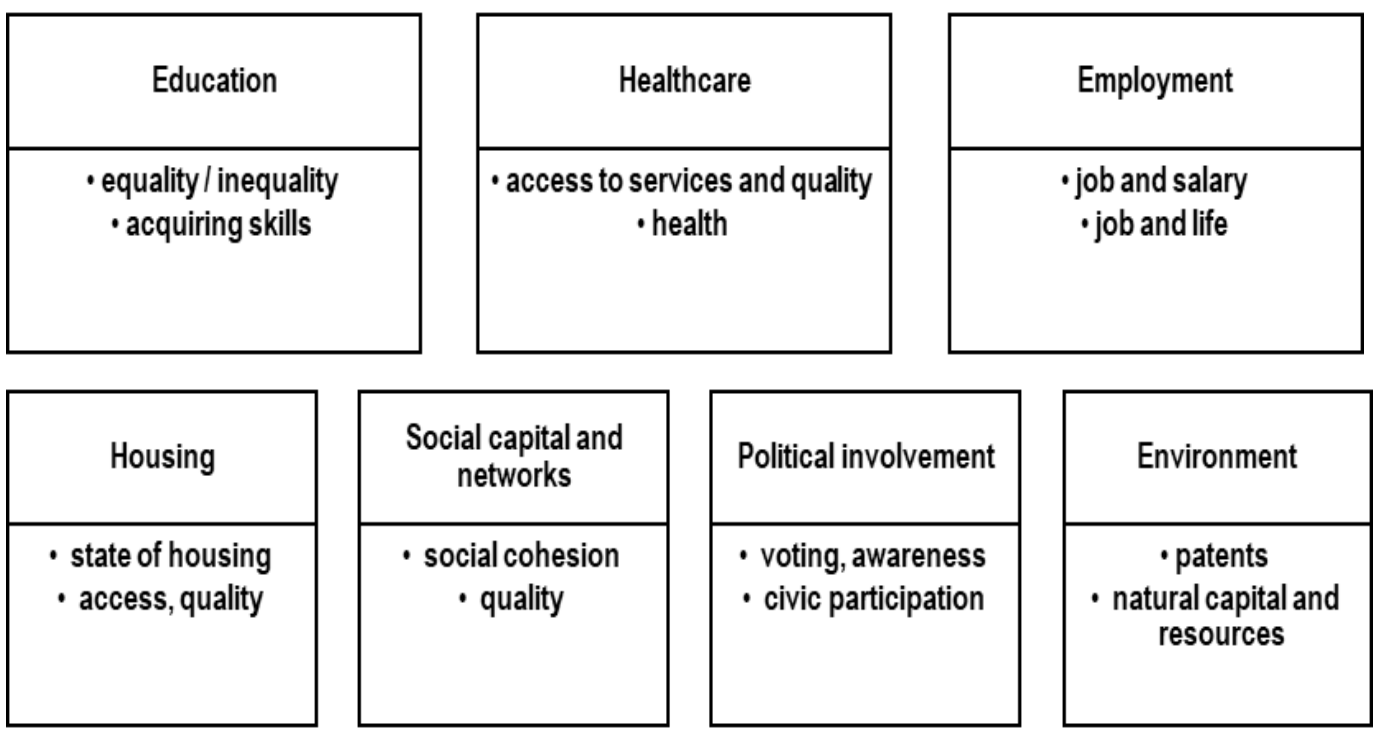
Figure 3 Critical areas in the most disadvanteged settlements Source: own editing

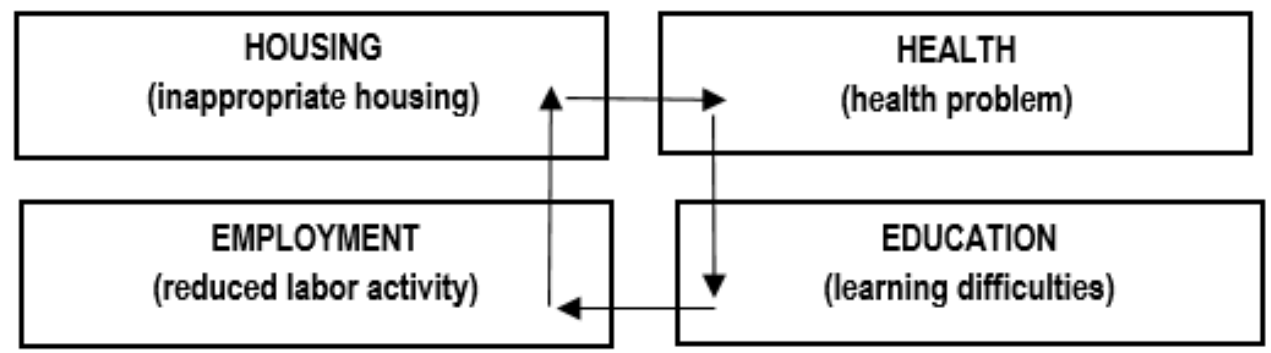

Figure 8: Long and short-term goals in education, Source: own compilation

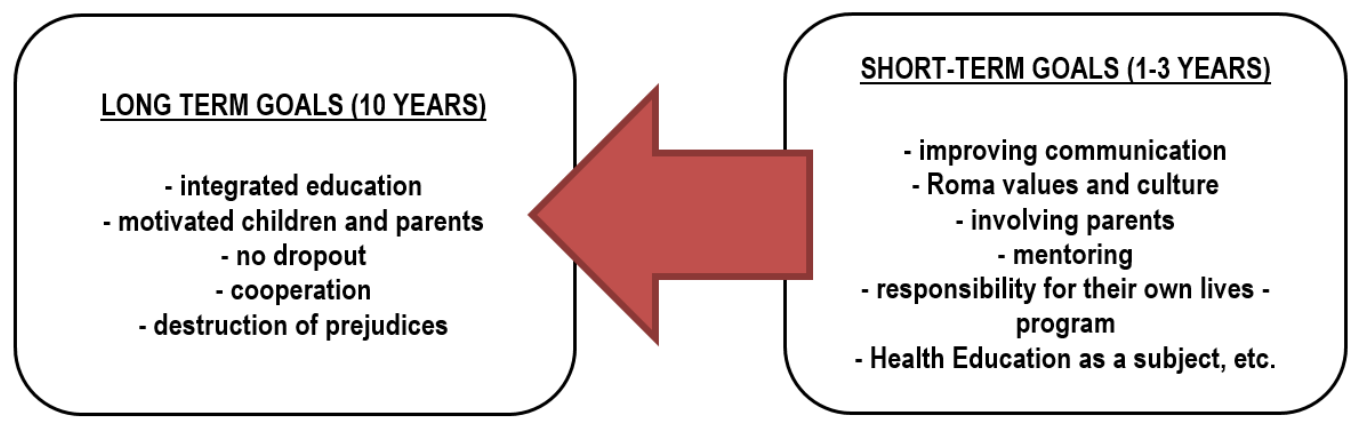

Figure 9 Long and short-term goals in employment, Source: own compilation

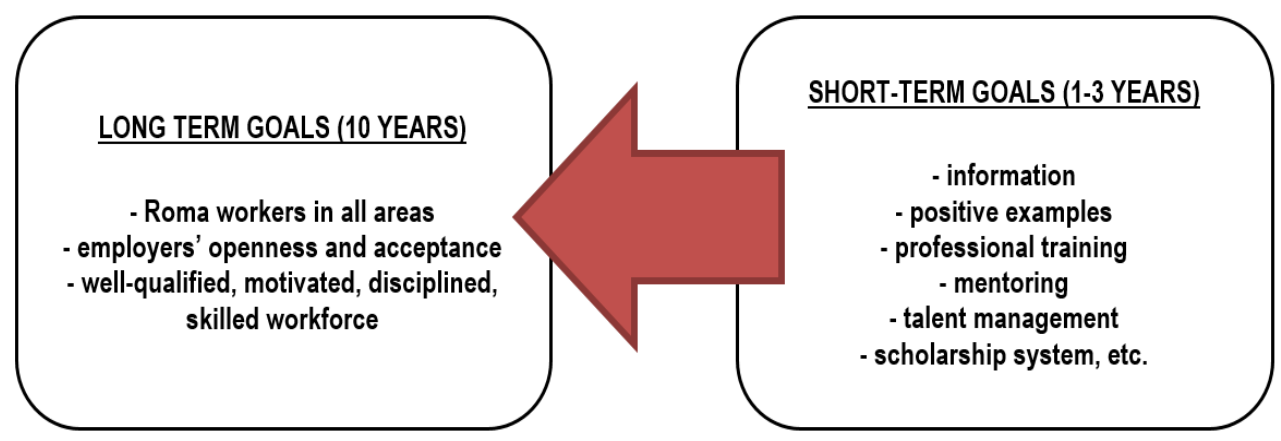

Figure 10 Frameworks of improving local living conditions

Source: own compilation based on The World Bank, 2015. 


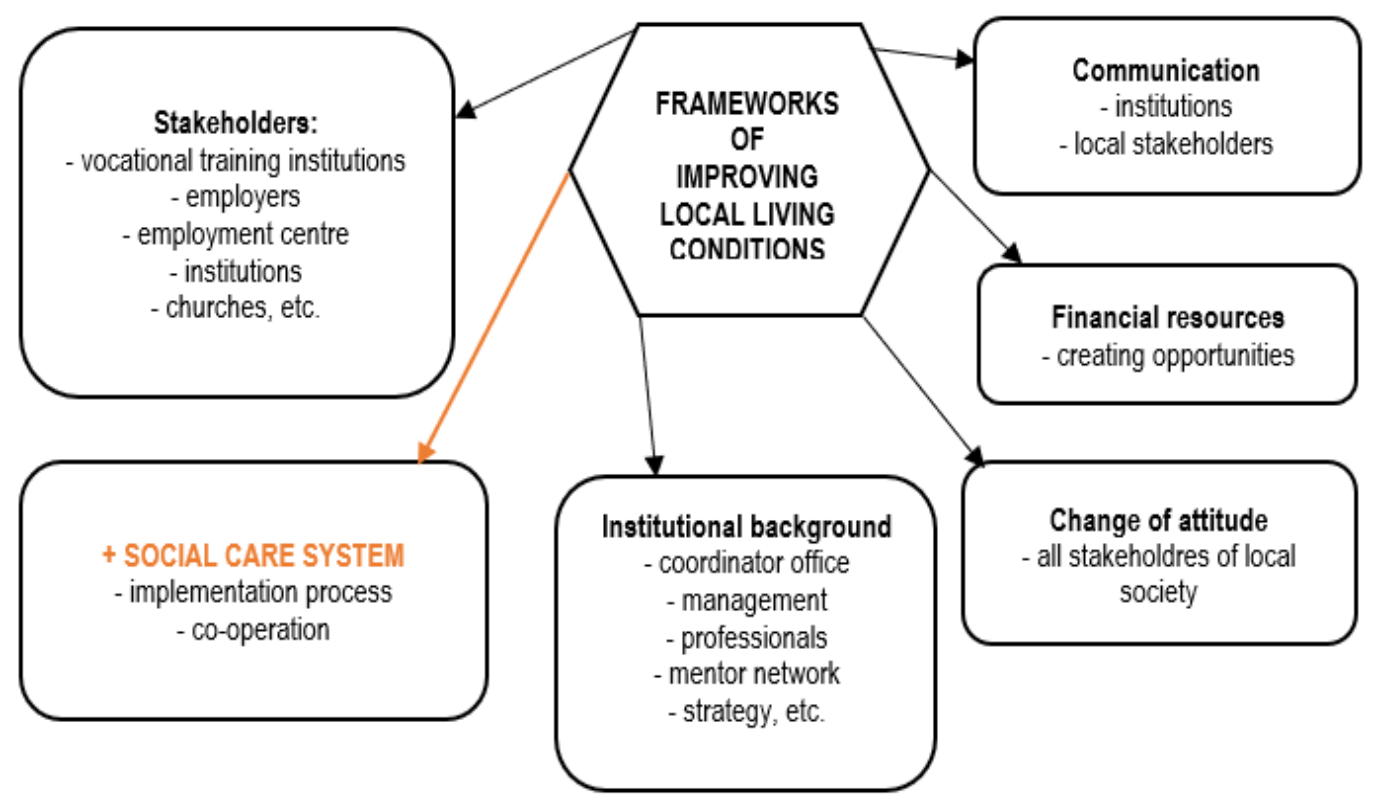

Figure 11 Measuring factors in municipal social innovation, Source: own compilation

\begin{tabular}{|c|c|c|c|}
\hline FRAMEWORK CONDITIONS & $\begin{array}{c}\text { SOCIAL INNOVATION } \\
\text { ACTIVITY } \\
\text { - prer-conditions } \\
\text { - sustainability conditions }\end{array}$ & $\begin{array}{c}\text { REGION SPECIFIC } \\
\text { RESULTS } \\
\text { - new self-government } \\
\text { structures, initiatives, } \\
\text { cooperation }\end{array}$ \\
\cline { 2 - 4 } & - education \\
- employment \\
- housing \\
- healthcare
\end{tabular}

